УДК 390(=941.11)(571.6)

\title{
Sociocultural Dynamics of the Ethnical Processes of the Evenks
}

\author{
Victor P. Krivonogov* and Elizaveta S. Ermilova \\ Siberian Federal University \\ 79 Svobodny, Krasnoyarsk, 660041, Russia
}

Received 26.08.2018, received in revised form 24.10.2018, accepted 07.11.2018

\begin{abstract}
In the years 1997 and 2017 in Evenkia, comprehensive studies in the form of a mass survey were carried out. They revealed some significant changes in the household, various aspects of material and spiritual culture. The scale of reindeer breeding has dramatically dropped; at the present moment, around 1/10 of the Evenk families are engaged in it. Hunting and fishing are preserved better: almost one third of all men are engaged in them. The overwhelming majority of men continue hunting and fishing at the amateur level, just like the major part of women maintain their sewing and beadwork skills. The language assimilation process is very active; children hardly speak or understand their mother tongue, though the majority of the Evenks study it at school. The share of mixed families, mostly with Russians, has reached fifty per cent: the majority of children from these families get assimilated with the Evenk ethnicity. As a result of such marriages, the share of people of mixed descent among the Evenks is approaching two thirds, while among the children this share has reached 9/10. The Evenks are mixing with other ethnicities and acquire Russian language, but maintain a stable ethnic self-consciousness and preserve certain elements of their traditional culture in some aspects of material and spiritual culture.
\end{abstract}

Keywords: Ethnic processes, linguistic assimilation, mixed marriages, miscegenation, ethnic self-consciousness.

The reported study was funded by Vostsibneftegaz, JSC within the research project "Revival of Evenki language".

Research area: sociology.

Citation: Krivonogov, V.P., Ermilova E.S. (2018). Sociocultural dynamics of the ethnical processes of the Evenks. J. Sib. Fed. Univ. Humanit. soc. sci., 11(11), 1845-1871. DOI: 10.17516/1997-1370-0344.

Contemporary ethnic processes occurring in the environment of the smallnumbered indigenous peoples of the North, Siberia and the Far East, are distinctive with

(C) Siberian Federal University. All rights reserved

* Corresponding author E-mail address: victor950@yandex.ru

This work is licensed under a Creative Commons Attribution-NonCommercial 4.0 International License (CC BY-NC 4.0). 
a number of features noticed by modern researchers (Anderson, 1991, 1998; Dolgikh and Chard, 1972; Grenoble and Whaley, 1999; Koptseva and Kirko, 2014a, 2014b, 2014c; Leonard et al. 1994 and others). The traditional economic activities underlying the culture of these peoples are receding into past. This process is unstoppable. The forms of ethnic manifestation and ethnic self-identification determinants are changing. They are exposed to both global and ethnic processes. For the representatives of the indigenous peoples resident in the Krasnoyarsk Territory (Krai) it is also relevant that the lands of their historical residence happen to be in the area of attention of large financial and industrial groups developing their large investment processes there.

The Evenks are a small-numbered indigenous people, with the majority of it living in the territory of the Evenki Municipal District. Previously it was an independent constituent entity of the Russian Federation, the Evenki Autonomous Okrug. Among the traditional occupations of the Evenks, there are: hunting, domestic reindeer breeding, fishing, wild plants foraging. Today, domestic reindeer breeding is maintained in the Evenki Municipal District only at Surindinsky municipal enterprise (Surinda Village, the Krasnoyarsk Territory (Krai)). For an ethnological research is it important to notice the current dynamics of the ethnic processes of the Evenks, as the factors of these dynamics are truly unique (Koptseva and Kirko, 2015; Libakova et al., 2014; Mamontova, 2014; Reznikova et al., 2014; Safonova and Sántha, 2011; Simonova, 2012; Ssorin-Chaikov, 2001; Whaley, 2011 and others).

The objective of the article is to demonstrate the main tendencies in the modern ethnic processes of the Western Evenks resident within the current borders of the Krasnoyarsk Territory (Krai) on the basis of an interval field research.

One of the tasks is to describe the linguistic situation of the Evenks in various demographic groups. It can be used to make a forecast of the Evenki language in the nearest future and to model the main actions applicable to preserve the language and the Evenki cultural heritage as a whole.

\section{Materials and methods}

In the year 1997, one of the authors of the article carried out a comprehensive research on the studies of modern ethnic processes of the Evenks resident in the Evenki Autonomous Region. The research incorporated various methods, concentrated around a mass survey with a special ethnographic questionnaire, which provided a rich material for judging not only about the past and the present of the Evenks, but also for making certain forecasts about their future. $25 \%$ of all the Evenks living in 
the Okrug were polled. As a result, a monograph and a series of articles were written (Krivonogov, 2001a, 2001b, 2001c).

In the year 2017, it was decided to repeat the research based on the same programme to evaluate the dynamics of the ethnic processes. Just like 20 years ago, 6 settlements were selected on the basis of their size, national composition, and location within the Okrug. The sampling included the settlements of Surinda, Uchami (predominantly populated by the Evenks), Nidym, Poligus (mixed population), Baykit and Tura (large settlements with predominantly Russian population). The survey covered whole families, answers for children aged under 16 being were provided by their parents. The survey considered the gender and the age of the respondents, the ratio of social and professional groups, the number of monoethnic and mixed families and other properties. In all characteristics, the sampling corresponds to the general situation and is acknowledged as a representative one.

\section{Results}

In the territory of the Evenki Municipal District, the Evenks constitute a minor, constantly decreasing share of the population. In the year 1970, with the total population of the Okrug of 12.7 thousand people, there were 3.2 thousand or $25.3 \%$ of the Evenks. In the year 1989, there were 24.8 thousand and 3.5 thousand (14.0\%) of them correspondingly (based on the relevant population census). However, in the 1990$\mathrm{s}$, the migrant population inflow ceased, and its share began to decrease. According to the census of the year 2010, the population of Evenkia is 16.3 thousand people, with 3583 , or $22.1 \%$ of them being the Evenks.

The number of the Evenki population is fluctuating, growing and decreasing, but basically remaining stable. In the past 20 years, the birth and death rates have been almost identical, with the natural population increase close to zero. The population is also influenced by migration from the municipal district. Low birth rate is proved by the average family size. It is not big and close to that of Russians. In 1997, the average family size within the sampling area was 3.8 people in a family; now, it is 3.6.

The majority of the settlements where the Evenks live, are ethnically mixed (Tutonchany, Nidym, Kislokan, Poligus, Osharovo, Kuyumba). There are few monoethnic settlements (Surinda, Ekonda etc.). In the former Okrug and two district centres (Tura, Baykit, Vanavara), the majority of population were migrants, and the percentage of the Evenks in the large and seemingly industrial settlements had always been small. However, the Evenki migration to the settlements has been active 
throughout the past decades, and their absolute and relative share is growing (though Baykit and Vanavara have lost their status of district centres, the centre of the Okrug, Tura, is currently an administrative centre) (see Table 1).

Studying migrations in the context of the ethnic processes, it is important to find out how they influence the distribution of the Evenks with respect to other ethnicities. Is there a migration flow from the monoethnic settlements to the mixed ones? Do the Evenks tend to leave their ethnic territories? And, finally, is there a developing urbanization process? Obviously, the most favourable conditions for the preservation of the ethnic identity, traditional culture and language are found in the small monoethnic villages. The major part of the Evenki found themselves in the mixed ones. Is this established distribution tendency a stable factor, or do the migrations still make a difference?

In the 1970-80-s, the Evenks migrated from the monoethnic settlements to the mixed or predominantly Russian ones, especially to the district and okrug centres. It is proven by the share of the migrant Evenks among the adult population of the settlements with various ethnic composition. For instance, among the residents of the monoethnic settlement of Ekonda in 1997 it was 24.7\%, in the mixed settlement of Tutonchany it was $43.6 \%$, while in Tura and Baykit (together) it was $85.7 \%$. 20 years later, similar figures are observed: in the Evenki settlement of Surinda, the share of the adult Evenks born in other villages was $18.7 \%$, and in the centre of Evenkia, Tura, it was $80.0 \%$. However, there are some changes as well: active migration from the mixed but small settlements to the large Russian ones has begun. As a result, a half of the adult Evenks do not live where they were born (Table 2).

In the year $1997,18.0 \%$ of men and $33.1 \%$ of women were potential migrants (i.e. expressed their wish to change the place of residence). It is quite a high percentage, higher than that observed for other ethnicities of the North. The share of those for whom migration would mean the change of the ethnic environment is also high. Thus, $4.2 \%$ of men and $11.0 \%$ of women would like to move to the okrug or district centres; $7.7 \%$ of men and $17.4 \%$ of women were ready to move to a city; there were some people wishing to move to a settlement "on the continent" (in the South). Now, the share of potential migrants is $20.4 \%$ for men and $28.5 \%$ for women. That includes the $2.8 \%$ of men and $9.5 \%$ of women intending to move to the district centres of Evenkia, and $14.8 \%$ and $16.8 \%$ correspondingly wishing to leave Evenkia (for men, the share has dramatically increased, while for women it has negligibly decreased, but generally women are more eager to move than men). 
Table 1. Distribution of the Evenki population between settlements of various ethnic composition (based on expedition results, in per cent)

\begin{tabular}{|c|c|c|c|}
\hline \multirow{2}{*}{} & \multicolumn{3}{|c|}{ Ethnic composition of the settlement } \\
\cline { 2 - 4 } & $\begin{array}{c}\text { Predominantly Russian } \\
\text { (less than 20\% of Evenki) }\end{array}$ & $\begin{array}{c}\text { Mixed (from 20\% } \\
\text { to 80\% of Evenki) }\end{array}$ & $\begin{array}{c}\text { Evenki } \\
\text { (over 80\% of Evenki) }\end{array}$ \\
\hline 1997 & 25 & 46 & 29 \\
2017 & 55 & 24 & 21 \\
\hline
\end{tabular}

Table 2. Distribution of the Evenks by their place of birth (in per cent, based on the survey)

\begin{tabular}{|l|c|c|}
\hline \multicolumn{1}{|c|}{ Place of birth } & 1997 & 2017 \\
\hline place of survey & 46.3 & 49.8 \\
another settlement of the same district & 30.1 & 33.5 \\
another district of Evenkia & 6.9 & 7.7 \\
Irkutsk Oblast & 11.9 & 6.3 \\
the Far East & 1.9 & 1.0 \\
a settlement "on the continent" & 0.8 & - \\
cities of Russia & 2.1 & 1.7 \\
\hline Total & 100 & 100 \\
\hline
\end{tabular}

The higher is the education level, the more prominent is the wish to move to the okrug centre, district centres, to a city or beyond the ethnic territory. Thus, in 1997, among people with elementary education and below, the share of potential migrants was $8.7 \%$ for men; among those having an academic degree (complete or incomplete) that share was 2,8\%. Among women, it was $14.3 \%$ and $51.4 \%$ correspondingly. 20 years later, the pattern is still the same. Among both men and women having elementary education and below, there were no potential migrants at all, while among university graduates that share constituted $22.2 \%$ for men and $38.5 \%$ for women. At that, almost all potential migrants having a degree are planning to go outside Evenkia: $22.2 \%$ of men and $34.6 \%$ of women.

The share of potential migrants among the youth is especially high. In the year $1997,42.9 \%$ of boys and the same share of girls aged 16-19 were eager to change their place of residence, with $28.6 \%$ and $32.1 \%$ correspondingly planning to go to cities, with the rest wishing to go to the district centres of Evenkia. At the present moment, the share of boys who plan to move away is $40 \%$, with all of them moving to town; for girls, this share is $85.7 \%$, with $42.9 \%$ of them going to cities. It indicates high probability of the future change in the population pattern towards the less compact one, creating an environment for more interaction with other ethnicities.

The main activities of the Evenks have always been hunting, reindeer breeding, and fishing (Vasilevich and Levin, 1951; Strakach, 1962; Tugolukov, 1960, 1962, 
1963a, 1963b, 1965, 1974; Turov, 1972, 1990). For some groups, reindeer breeding was the dominating one; for others, hunting and fishing prevailed (Vasilevich, 1965: 706). Besides the nomad Evenks, there were sedentary and semi-sedentary ones.

Due to the enormous extensiveness of the Evenki territory, considering the fact that in the past they preferred to migrate around Russian settlements and villages, the preservation of their ethnicity as such had always depended on their loyalty to the traditional activities. The difference of economic activities was a serious barrier that did not allow the Evenks to assimilate. Shifting away from the traditional activities and settling down in mixed settlements often leads to assimilation with the migrant population, and sometimes, to the loss of ethnic identity. But even residing in a mixed settlement, the ethnos has a chance to preserve itself if the difference in activities remains unchanged; that means that traditional activities act as an obstacle for assimilation processes.

In the past decade of the $20^{\text {th }}$ century, the share of the Evenks engaged in the traditional economic activities has dramatically dropped; there are hardly any women engaged (only $4.1 \%$, Table 3 ), while for men this share is a little more than a quarter, with the hunting and fishing showing more stability than reindeer breeding that is obviously in a critical situation. The information provided by the authorities of Baykit and Tura indicates a dramatic decrease in the number of bred reindeer since the beginning of the 1990-s; in some Evenki villages, there are none left, and in others the reindeer population has dropped by $3-10$ times. It is explained by the unfortunate economic transformations of the early 1990-s, when the majority of collective farms (sovkhoz) were eliminated to be replaced with other kinds of economic establishments (tribal enterprises, family farms). Indeed, such transformations are worth a separate research; let us just point out at the consequences, such as decreasing domestic reindeer population and the forced shift of a significant share of the Evenks from reindeer breeding to hunting and other activities related to their new sedentary lifestyle. An enormous number of the Evenks was unemployed: one third of all men and one sixth of all women. However, later the situation improved, with the unemployment reduced by approximately two times and the number of people engaged in traditional activities remaining the same, constituting $31.0 \%$ of men and $5.0 \%$ of women (Table 4 ).

For the traditional activities done as a hobby, not as work, the survey shows an absolutely different situation. $94.4 \%$ of men and $77.3 \%$ of women are engaged in such activities. Around one half of men (55.4\%) are, or, to be more precise, used to be related to reindeer breeding, but this figure was rapidly decreasing, as the former reindeer breeders 
Table 3. Social and professional groups of the Evenks in 1997 (based on the survey, per cent)

\begin{tabular}{|l|c|c|c|c|c|c|c|}
\hline \multirow{2}{*}{} & \multicolumn{7}{|c|}{ Social and professional groups } \\
\cline { 2 - 8 } & $\begin{array}{c}\text { Traditional } \\
\text { activities }\end{array}$ & $\begin{array}{c}\text { Unskilled } \\
\text { workers }\end{array}$ & $\begin{array}{c}\text { Skilled } \\
\text { workers }\end{array}$ & $\begin{array}{c}\text { Clerks and } \\
\text { specialists }\end{array}$ & Managers & Unemployed & Housewives \\
\hline Men & 26.2 & 18.9 & 7.9 & 6.1 & 7.4 & 33.5 & - \\
\hline Women & 4.1 & 34.7 & 2.5 & 34.3 & 6.6 & 17.0 & 0.8 \\
\hline
\end{tabular}

Table 4. Social and professional groups of the Evenks in 2017 (based on the survey, per cent)

\begin{tabular}{|c|c|c|c|c|c|c|c|c|}
\hline & \multicolumn{8}{|c|}{ Social and professional groups } \\
\hline & 总 & 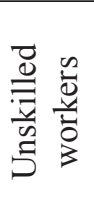 & 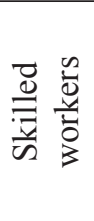 & 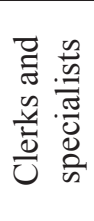 & 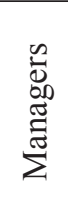 & 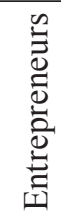 & 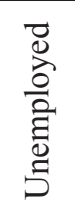 & 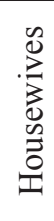 \\
\hline Men & 31.0 & 25.0 & 14.3 & 11.9 & 1.2 & 2.4 & 14.2 & - \\
\hline Women & 5.0 & 38.1 & 4.3 & 33.8 & 5.1 & - & 10.1 & 3.6 \\
\hline
\end{tabular}

shifted to hunting. By the end of the 1990 -s, only $16.9 \%$ of the Evenki families owned any reindeer, and only 3\% owned herds of over 50 heads. Many women preserved their skills of fur crafts and beadwork (Krivonogov, 1992: 179), national costume making, but they do it at home only; currently, women go to taiga less and less often.

At the same time, traditional activities are still popular as hobbies, with $89.7 \%$ of men and $73.7 \%$ of women engaged; however, the number of people having any reindeer breeding skills has significantly decreased to only $29.9 \%$ of men. In reality, only $10.2 \%$ of the Evenki families own any reindeer.

The education level has been consistently growing in the past decades, and, as everywhere else in the North, women have greatly outrun men in academic achievements. At the present time, there are hardly any illiterate or semiliterate people left; the number of adults with elementary education has also dropped. The share of people with secondary vocational and higher education degree is still growing; in the past 20 years, this indicator has changed from $24.4 \%$ to $32.6 \%$ for men and from $41.6 \%$ to $48.2 \%$ for women (Table 5). At the same time, the number of people with incomplete secondary education has also increased (from $30.4 \%$ to $37.8 \%$ for men and from $19.8 \%$ to $31.5 \%$ for women).

This way, in the past decades the difference in the economic activities of the Evenks and Russian population has greatly decreased. Many Evenks do almost the same things 
Table 5. Education level of the Evenks in the years 1997 and 2017 (based on the surveys, per cent)

\begin{tabular}{|l|c|c|c|c|c|c|c|}
\hline & \multicolumn{7}{|c|}{1997} \\
\cline { 2 - 8 } & $\begin{array}{c}\text { Below } \\
\text { elementary }\end{array}$ & Elementary & $\begin{array}{c}\text { Incomplete } \\
\text { secondary }\end{array}$ & $\begin{array}{c}\text { General } \\
\text { secondary }\end{array}$ & $\begin{array}{c}\text { Secondary } \\
\text { vocational }\end{array}$ & $\begin{array}{c}\text { Incomplete } \\
\text { higher }\end{array}$ & $\begin{array}{c}\text { Higher } \\
\text { education } \\
\text { degree }\end{array}$ \\
\hline Men & 1.7 & 8.8 & 30.4 & 34.7 & 12.7 & 3.9 & 7.8 \\
Women & 2.8 & 4.4 & 19.8 & 31.4 & 28.5 & 4.0 & 9.1 \\
\hline \multicolumn{7}{|c|}{2017} & \\
\hline Men & - & 6.1 & 37.8 & 23.5 & 23.5 & 1.0 & 8.1 \\
Women & - & 2.3 & 31.5 & 18.0 & 33.1 & 0.6 & 14.5 \\
\hline
\end{tabular}

as Russians living next door. From all various kinds of economic activities, the only one that became a barrier for assimilation processes is nomadic reindeer breeding, but currently only one in ten families is engaged in it. Combined with sedentary lifestyle, hunting and fishing hardly perform any preserving functions (Krivonogov, 2001: 27). It explains the active interaction between the indigenous and migrant population, which usually triggers the development of assimilation processes.

The material Evenki culture is closely connected to their economic activity. Naturally, a massive shift from the traditional activities and general lifestyle changes made an inevitable impact on the material culture: many of its elements began to disappear and some of them transformed to adjust.

At the beginning of the $20^{\text {th }}$ century, the Evenks preferred wearing traditional clothes. The survey of the year 1997 revealed that over a half of the interviewed Evenks (56.8\%) owned some national clothes, but only $18.1 \%$ actually had a complete costume. $55.8 \%$ of men and $60.3 \%$ of women claimed to have some traditional clothes (with $25.5 \%$ of men and $12.3 \%$ of women having a complete costume). Now the share has significantly dropped to $25.8 \%$ for men (6.1\% having a complete costume) and $27.8 \%$ for women (3.2\% having a complete costume). The youth keeps traditional clothes even less: $12.1 \%$ of boys (and no full costumes at all) and 15\% of girls. Besides personal national clothes, stylized ethnic costumes for stage performances are found at some cultural establishments to be used by vocal and dancing ensembles, that are quite numerous in Evenkia (generally, at the institutions of education and culture).

Household items, working tools, various traditional utensils have always been closely connected to traditional economic activities, and as the Evenks began to prefer other spheres, the use of such also found a decline. But they do not disappear 
completely at least for the reason that many Evenks continue doing traditional activities as a hobby, which means that the need for such things still remains. The Evenks used to craft reindeer harness, riding and cargo saddles. For cargo transportation, crossover saddle bags of deer skin on the birch bark base were made. For moving along the rivers, dugout canoes were used. Sometimes it was also possible to come across some boats of plank board or birch bark (Vasilevich, 1956: 712). The Evenks used wide skis, with no lining on snow crust and lined with deer skin on deep snow. The household items were made of wood and birch bark; among the store-bought tableware, the most frequently used ones were cups and kettles (Vasilevich, 1956: 720). By the beginning of the $19^{\text {th }}$ century, fire arms had replaced arches and arrows. Among the traditional working tools and weapon, the only one that is still used is the so-called "palm", a large knife with a long handle, serving as both an axe and a spear.

20 years ago, these or those traditional material items (except for clothes) could be found in $54.4 \%$ of the Evenki families. Skin dressing tools were found in $45.4 \%$ of families; harnesses and other reindeer breeding items (saddle-bags, sledges) in $45.4 \%$ of families; reindeer riding gear - in 12.6\%, home-made hunting $(21.7 \%)$ and fishing (16.3\%) accessories, traditional skis - in $28.2 \%$, dugout boats - in $12.1 \%$ of families.

At the present time the share of families still keeping these items has reduced to $38.2 \%$. Such items are more common for monoethnic villages. Thus, 20 years ago in such villages, $64.2 \%$ of the Evenki families owned traditional household items and utensils, for mixed villages this share was $61.2 \%$, and for predominantly Russian it was $41.7 \%$. At the present time, the indicators have reduced for all types of settlements: to $60.5 \%$ of families in monoethnic villages, $42.9 \%$ in mixed villages and $29.2 \%$ in predominantly Russian villages. In mixed and Russian settlements such things grow out of use faster, as the population there has shifted away from the traditional activities to a greater extent.

In the early $20^{\text {th }}$ century, the ethnic cuisine of the Evenks mostly consisted of dishes of game and fish; moreover, under the influence of Russians, bread became ingrained in the Evenki diet (Vasilevich, 1956: 716). Just like everywhere else in the North, ethnic dishes do not constitute the foundation of the diet anymore; they are mostly seen as a supplement to dishes of store-bought goods. In single-parent families with no men to do hunting, traditional dishes are rarely cooked. The men engaged in traditional hunting or fishing, consume traditional dishes more often than women.

Ethnic cuisine is familiar to the predominant majority of the Evenks; in the year 1997 , such dishes were consumed by $92.3 \%$ of men and $82.2 \%$ of women, regularly $53.3 \%$ of men and $37.1 \%$ of women. In the past 20 years, these values have not changed 
a lot, which proves the great stability of this kind of material culture. At the moment, ethnic cuisine dishes are consumed by $93.5 \%$ of men and $88.8 \%$ of women, regularly $49.1 \%$ and $33.5 \%$ correspondingly. The share of men here is greater than that of women, because they are more involved in taiga, hunting and fishing activities.

According to the census of $1979,86.1 \%$ of the Evenks referred to Evenki language as their mother tongue; in 1989 , this value was $73.7 \%$, and in 2010 it reduced to $44.0 \%$. The command of Russian language has approached $100 \%$. It became dominating in the language behaviour of the Evenks. In 1997, as the only mother tongue, Evenki language was recognized by $31.3 \%$ of the polled Evenks; $7.2 \%$ claimed to have two equal mother tongues, Russian and Evenki, and $61.5 \%$ of the Evenks said they spoke only Russian as their mother tongue. At the present moment, the rates are $14.0 \%, 19.8 \%$, and $66.2 \%$ correspondingly.

The level of language command is directly connected to the place of residence (Table 6).

The dynamics of the current language situation is obvious both in the comparison of values for two dates and in the comparison of values by various age groups (Table 7).

Even those who recognize Evenki language as their mother tongue, hardly ever use it in life. This is proved by the values obtained for the preferred language communication. Even in the year 1997, the number of those, for whom Evenki language was the main way of everyday communication, was only $4.3 \%$. Now, there are hardly any of them left: $0.4 \%$. The share of those who use both languages equally has also reduced, from $16.8 \%$ to $10.7 \%$. For the remaining $88.9 \%$ (or $78.9 \%$ twenty years ago) the main communication language is Russian. The distribution of this value by age groups has shown that Evenki language was not that common among children and youth even 20 years ago, and now it is hardly ever used by them (Table 8).

During the last 20 years, the level of Evenki language command has dramatically dropped (Table 9). The decline was observed in both Evenki and mixed settlements (Table 10).

The dynamics of this value for different age groups unambiguously points at the decline in the number of children and young people who speak Evenki language (Table 11). There are hardly any children fluent in Evenki, and $85.2 \%$ of children aged under 10 just do not understand it, even though they are taught it at school (20 years ago, their share was $71.3 \%$ ).

To a certain extent, Yakut language is also used, for it is the neighbour ethnicity the Evenks have been interacting with for quite a long time. However, the total number of people familiar with that language is not big; those are mostly members of mixed 
Table 6. Mother tongue of the Evenks resident in settlements of various ethnic compositions

\begin{tabular}{|l|c|c|c|c|c|c|}
\hline & \multicolumn{3}{|c|}{1997} & \multicolumn{3}{c|}{2017} \\
\cline { 2 - 7 } & Evenki & $\begin{array}{c}\text { Both } \\
\text { languages }\end{array}$ & Russian & Evenki & $\begin{array}{c}\text { Both } \\
\text { languages }\end{array}$ & Russian \\
\hline Evenki settlements & 36.1 & 6.8 & 57.1 & 25.8 & 28.0 & 46.2 \\
Mixed settlements & 29.1 & 6.9 & 64.0 & 19.3 & 13.7 & 67.0 \\
Russian settlements & 28.9 & 8.1 & 63.0 & 7.2 & 19.4 & 73.4 \\
\hline
\end{tabular}

Table 7. Mother tongue of the Evenks of various age groups (based on the survey, in per cent)

\begin{tabular}{|c|c|c|c|c|c|c|}
\hline \multirow{3}{*}{ Age } & \multicolumn{3}{|c|}{1997} & \multicolumn{3}{|c|}{2017} \\
\hline & \multicolumn{6}{|c|}{ Mother tongue } \\
\hline & $\begin{array}{c}\text { Evenki } \\
\text { language }\end{array}$ & $\begin{array}{c}\text { Both } \\
\text { languages }\end{array}$ & $\begin{array}{c}\text { Russian } \\
\text { language }\end{array}$ & $\begin{array}{c}\text { Evenki } \\
\text { language }\end{array}$ & $\begin{array}{c}\text { Both } \\
\text { languages }\end{array}$ & $\begin{array}{c}\text { Russian } \\
\text { language }\end{array}$ \\
\hline 70 and older & 85.7 & - & 14.3 & 90.9 & 9.1 & - \\
\hline $60-69$ & 83.3 & 11.1 & 5.6 & 64.7 & 35.3 & - \\
\hline $50-59$ & 86 & 2 & 12 & 44.7 & 25.5 & 29.8 \\
\hline $40-49$ & 75.5 & 11.8 & 12.7 & 20.5 & 40.9 & 38.6 \\
\hline $30-39$ & 60.4 & 7.6 & 32 & 12.1 & 30.3 & 57.6 \\
\hline $20-29$ & 22.5 & 9.8 & 67.7 & 4.7 & 24.7 & 70.6 \\
\hline $10-19$ & 4.1 & 7.7 & 88.2 & - & 8.3 & 91.7 \\
\hline Under 10 & 2.5 & 4.2 & 93.3 & - & 4.6 & 95.4 \\
\hline
\end{tabular}

Table 8. Main communication language of the Evenks of different age groups (based on the survey, in per cent)

\begin{tabular}{|l|c|c|c|c|c|c|}
\hline \multirow{2}{*}{ Age } & \multicolumn{3}{|c|}{1997} & \multicolumn{3}{c|}{2017} \\
\cline { 2 - 7 } & $\begin{array}{c}\text { Evenki } \\
\text { language }\end{array}$ & $\begin{array}{c}\text { Both } \\
\text { languages }\end{array}$ & $\begin{array}{c}\text { Russian } \\
\text { language }\end{array}$ & $\begin{array}{c}\text { Evenki } \\
\text { language }\end{array}$ & $\begin{array}{c}\text { Both } \\
\text { languages }\end{array}$ & $\begin{array}{c}\text { Russian } \\
\text { language }\end{array}$ \\
\hline 70 and older & 14.3 & 35.7 & 50 & - & 18.2 & 81.8 \\
$60-69$ & 25 & 52.8 & 22.2 & 5.9 & 52.9 & 41.2 \\
$50-59$ & 12 & 52 & 36 & - & 29.8 & 70.2 \\
$40-49$ & 5.9 & 41.2 & 52.9 & 2.3 & 9.1 & 88.6 \\
$30-39$ & 7.6 & 25.7 & 66.7 & - & 16.4 & 83.6 \\
$20-29$ & 1.5 & 9 & 89.5 & - & 6 & 94 \\
$10-19$ & 1.4 & 3.1 & 95.5 & - & 1.4 & 98.6 \\
Under 10 & 0.4 & 4.2 & 95.4 & - & 1.9 & 98.1 \\
\hline
\end{tabular}

Table 9. Level of the Evenks' command of Evenki language (based on the survey, in per cent)

\begin{tabular}{|l|c|c|c|c|c|}
\hline & Fluently & $\begin{array}{c}\text { With some } \\
\text { difficulty }\end{array}$ & $\begin{array}{c}\text { With significant } \\
\text { difficulty }\end{array}$ & $\begin{array}{c}\text { Understand but } \\
\text { do not speak }\end{array}$ & No command \\
\hline 1997 & 31.1 & 4.4 & 9.2 & 21.1 & 34.2 \\
2017 & 15.1 & 6.0 & 12.2 & 25.4 & 41.3 \\
\hline
\end{tabular}


Table 10. Level of the Evenks' command of Evenki language in settlements of various ethnic composition (based on the surveys of 1997 and 2017, in per cent)

\begin{tabular}{|l|c|c|c|c|c|}
\hline \multicolumn{1}{|c|}{$\begin{array}{c}\text { Types of } \\
\text { settlements }\end{array}$} & Fluently & $\begin{array}{c}\text { With some } \\
\text { difficulty }\end{array}$ & $\begin{array}{c}\text { With significant } \\
\text { difficulty }\end{array}$ & $\begin{array}{c}\text { Understand but } \\
\text { do not speak }\end{array}$ & No command \\
\hline 1997 & 38.5 & 4.1 & 12.2 & 19.9 & 25.3 \\
Evenki & 27.9 & 3.3 & 6.6 & 24.0 & 38.2 \\
Mixed & 27.3 & 5.8 & 9.3 & 19.0 & 38.6 \\
Russian & & & & & \\
\hline 2017 & 24.7 & 14.0 & 12.9 & 20.4 & 28.0 \\
Evenki & 18.4 & 4.6 & 17.4 & 22.0 & 37.6 \\
Mixed & 10.1 & 3.6 & 9.7 & 28.6 & 48.0 \\
Russian & & & & & \\
\hline
\end{tabular}

Table 11. Level of Evenki language command in different age groups (based on the survey, 1997 , in per cent)

\begin{tabular}{|l|c|c|c|c|c|}
\hline \multicolumn{1}{|c|}{ Age } & Fluently & $\begin{array}{c}\text { With some } \\
\text { difficulty }\end{array}$ & $\begin{array}{c}\text { With significant } \\
\text { difficulty }\end{array}$ & $\begin{array}{c}\text { Understand but } \\
\text { do not speak }\end{array}$ & No command \\
\hline 1997 & & & & & \\
70 and older & 85.7 & 14.3 & - & - & - \\
$60-69$ & 86.1 & 8.3 & 5.6 & - & - \\
$50-59$ & 86.0 & 4.0 & - & 8.0 & 2.0 \\
$40-49$ & 78.4 & 4.9 & 3.9 & 9.8 & 3.0 \\
$30-39$ & 55.6 & 6.2 & 16.0 & 14.6 & 7.6 \\
$20-29$ & 19.5 & 5.3 & 19.5 & 34.6 & 21.1 \\
$10-19$ & 5.0 & 3.6 & 11.7 & 30.8 & 48.9 \\
Under 10 & 3.7 & 2.1 & 2.5 & 20.4 & 71.3 \\
\hline 2017 & & & & & \\
70 and older & 81.8 & 18.2 & - & - & - \\
$60-69$ & 70.6 & 17.6 & 5.9 & 5.9 & - \\
$50-59$ & 53.2 & 6.4 & 6.4 & 29.8 & 18.2 \\
$40-49$ & 25.0 & 11.3 & 27.3 & 18.2 & 20.9 \\
$30-39$ & 14.9 & 10.5 & 20.9 & 32.8 & 35.7 \\
$20-29$ & 1.2 & 5.9 & 15.5 & 41.7 & 55.5 \\
$10-19$ & - & 1.4 & 13.9 & 29.2 & 85.2 \\
Under 10 & - & 0.9 & 1.9 & 12.0 & \\
\hline
\end{tabular}

Yakut-Evenki families. The share of people familiar with Yakut language was $1.8 \%$ of the respondents, but none of them were fluent in it.

In what situations are two main languages used within the family and outside? Evenki language is used in communication with parents relatively more frequently, but in all situations Russian language prevails over it. In 20 years, the rate of using Evenki language in all situations has declined (Table 12).

Evenki language has a writing; it was included into school curriculum quite a long time ago. At the present moment, $81.3 \%$ of the interviewed school students and adults 
Table 12. Usage of the main communication languages in different situations by the Evenks (based on the survey, in per cent)

\begin{tabular}{|l|c|c|c|c|c|c|}
\hline \multirow{2}{*}{$\begin{array}{c}\text { Use in communication } \\
\text { with: }\end{array}$} & \multicolumn{3}{|c|}{1997} & \multicolumn{3}{c|}{2017} \\
\cline { 2 - 7 } & $\begin{array}{c}\text { Evenki } \\
\text { language }\end{array}$ & $\begin{array}{c}\text { Both } \\
\text { languages }\end{array}$ & $\begin{array}{c}\text { Russian } \\
\text { language }\end{array}$ & $\begin{array}{c}\text { Evenki } \\
\text { language }\end{array}$ & $\begin{array}{c}\text { Both } \\
\text { languages }\end{array}$ & $\begin{array}{c}\text { Russian } \\
\text { language }\end{array}$ \\
\hline Parents & 23.9 & 28.1 & 48.0 & 6.7 & 33.3 & 60.0 \\
Brothers, sisters & 15.7 & 13.2 & 71.1 & 2.9 & 16.7 & 80.4 \\
Friends & 3.8 & 25.3 & 70.9 & 1.7 & 14.0 & 84.3 \\
Partners & 12.0 & 27.6 & 60.4 & 2.0 & 18.4 & 79.6 \\
Children & 4.4 & 22.1 & 73.5 & 0.5 & 16.1 & 83.4 \\
At work & 5.2 & 22.2 & 72.6 & 1.6 & 20.1 & 78.3 \\
\hline
\end{tabular}

replied that they studied Evenki language at school, including 20.8\% at elementary school, 53.3\% before grade 9, and 8.2\% at high school. But the share of those able to read and write in Evenki language is relatively small, and it is obviously declining. In the year 1997, 37.0\% of adults and school children (aged 7 and above) claimed they could read and write in Evenki language and 20.1\% said they could only read. In 2017, these numbers were 29.3 and 20.3 correspondingly.

As for Russian, there are no problems: $96.4 \%$ of the Evenks could read and write in Russian 20 years ago and $99.4 \%$ can read and write in it today (the remaining $0.6 \%$ can only read). The only ones who could neither read nor write were very old people, but in the 20 years they have passed away.

Studying the language at school does not save the Evenks from the language assimilation: children hardly have any command of it. It proves one more time that the basics of the mother tongue are established within the family, not at school, and not starting from the age of seven, but from the moment the child is born. But since Evenki language is not used in the families in the more, it draws some really unfortunate results.

In various aspects of spiritual culture, the two languages interact, and Russian dominates in many situations.

Oral folk arts of the Evenks consisted of improvised songs, new songs, myths, tales about animals, legends, magic spells etc. (Vasilevich, 1956: 729). Evenki language is still widely used in the song genre. Besides the natural succession of folklore, it is passed down through schools, clubs, amateur talent groups; recently, the second option obviously prevailed. Despite the language deformation, in the past 20 years the situation has hardly changed. But in the year 1997, 2.2\% of all the Evenks aged over seven sang in Evenki only; 33.6\% of them sang in two languages and 61\% - in Russian. 
Today, $6.2 \%$ of the interviewed prefer singing in Evenki, $25.9 \%$ sing in both languages and $60.9 \%$ do it only in Russian. And even though there are more Evenks singing in Russian, the fact of stopping the process of replacing the ethnic language from this form of spiritual culture indicates the success of the local cultural and education bodies in the hard work of preserving the ethnic culture. Even though the decline of the language factor in the genre for the younger age group is found (Table 13), in 20 years the figures remained the same. It means that those who did not sing in Evenki in their childhood, later took up the art.

In the year 1997, 14.6\% of all the respondents aged over 7 knew more than five Evenki songs; $31.0 \%$ knew at least one or several songs, and the remaining $54.4 \%$ knew none. 20 years after, the values changed, but not dramatically. More than five songs are familiar to $9.9 \%$, five and less - to $36.3 \%$, and $53.8 \%$ do not know any Evenki songs. And even though over a half of the Evenks do not know any ethnic songs, this number has not increased in the past 20 years, which can be considered a success of the local institutions of culture and education. Among the old people, $78 \%$ knew at least one or several Evenki songs; among children and youth aged $8-19$, this share was only $23.5 \%$. However, 20 years later the figures changed just a little ( $67.9 \%$ for old people, $23.8 \%$ for children and youth aged under 20). It means that those who were initially unfamiliar with the song culture or had poor knowledge of it, have begun to learn. Even in the youngest age group, the genre of songs is partially acquired.

For such kind of folklore as fairy tales the situation is similar. In 1997, 17.6\% of the Evenks (aged over 8) knew more than three fairy tales. 11.9\% know at least 1-3 fairy tales. There are people who have heard some fairy tales but do not remember them by heart: they constitute 29.6\%. The remaining 40.9\% have never heard any Evenki fairy tales at all.

In the past 20 years these figures have declined but not considerably. $20.3 \%$ of the respondents claimed to remember more than three fairy tales; 8.7\% know at least 1-3 fairy tales, $27.9 \%$ do not know them by heart but they have heard them before, and $43.1 \%$ declare being unfamiliar with the genre. The rates are stabilized due to learning the fairy tales at elementary school. For older age groups, the rate of those familiar with the genre is higher, but 20 years after the rates shown by various age groups have hardly changed.

The traditional wedding ritual was quite wide-spread among the Evenks even in the early $20^{\text {th }}$ century. The people practiced several burial methods; after the contact with Russians, Orthodox Christian rituals began to take over. 
Table 13. Language of singing in different age groups of the Evenks (based on the survey of 1997, in per cent)

\begin{tabular}{|l|c|c|c|c|}
\hline \multirow{2}{*}{ Age } & \multicolumn{4}{|c|}{ Language of songs } \\
\cline { 2 - 5 } & Evenki & Both languages & Russian & Do not sing \\
\hline 1997 & & & & \\
60 and older & 14.0 & 58.0 & 24.0 & 4.0 \\
$40-59$ & 1.3 & 55.3 & 41.4 & 2.0 \\
$20-39$ & 2.2 & 34.6 & 59.2 & 4.0 \\
$7-19$ & 0.7 & 17.0 & 79.2 & 3.1 \\
\hline 2017 & & & & \\
60 and older & 3.6 & 57.1 & 21.4 & 17.9 \\
$40-59$ & 15.2 & 27.2 & 50.0 & 7.6 \\
$20-39$ & 4.0 & 24.5 & 63.6 & 7.9 \\
$7-19$ & 1.2 & 16.7 & 89.9 & 1.2 \\
\hline
\end{tabular}

Table 14. Familiarity of the Evenks with the main rituals (based on the surveys, in per cent)

\begin{tabular}{|c|c|c|c|c|c|c|c|c|}
\hline \multicolumn{3}{|c|}{ Birth } & \multicolumn{3}{|c|}{ Wedding } & \multicolumn{3}{|c|}{ Burial } \\
\hline 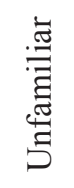 & 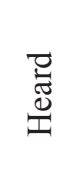 & 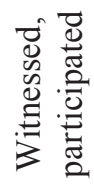 & 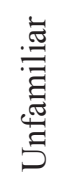 & 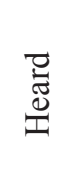 & 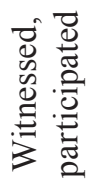 & 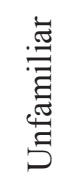 & 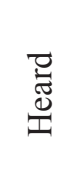 & 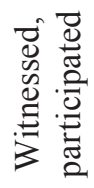 \\
\hline \multicolumn{9}{|c|}{1997} \\
\hline 86.6 & 10.7 & 2.7 & 78.7 & 18.4 & 2.9 & 49.7 & 26.1 & 24.2 \\
\hline \multicolumn{9}{|c|}{2017} \\
\hline 77.3 & 20.5 & 2.2 & 78.1 & 21.2 & 0.7 & 27.1 & 51.4 & 11.5 \\
\hline
\end{tabular}

Traditional rituals are practiced very rarely, though many people have heard of them. But, surprisingly, the rates for practicing the wedding and birth rituals, that were quite low in 1997, have not decreased until now (Table 14). And even though only few people had a chance to spectate these rituals in life, there are more respondents who have heard of them than 20 years ago. The awareness of the population of the burial ritual has also increased, despite there are less and less people who have actually seen it (the old people who lived in the times when they were practiced are now passing away).

The conservative burial ritual survives the best, though it has significantly changed, acquiring new, previously untypical elements.

Though the youth are much less familiar with all the rituals in comparison to the elderly people (in $2017,18.5 \%$ of the elderly and $43.8 \%$ of the young people have not heard of the traditional burial ritual, and for the wedding ritual the rates are $51.9 \%$ and 
$86.4 \%$ correspondingly), but with time, as they mature, the information is passed on to the next generations; for this reason, 20 years after the first survey the rates remained almost the same, which means that the information was reproduced.

The contemporary world outlook of the Evenks has been exposed to all the twists and turns of the ideological changes that have happened in the last centuries: there are those who identify themselves as Orthodox Christians, Atheists; there are adepts of more traditional mindsets. By the beginning of the $20^{\text {th }}$ century, the Evenki outlook had maintained some ancient forms of religious philosophy (Vasilevich, 1956: 727). Together with that, a certain influence was made by Orthodox Christianity, that began to spread when Russians appeared.

According to the survey, in $199744.9 \%$ of the respondents identified themselves as non-believers (Atheist); there were $26.8 \%$ of traditional religion followers, $18.5 \%$ of Orthodox Christians, and 7.9\% claimed to be both Orthodox Christian and adepts of the traditional world outlook. 1.9\% classified themselves as Protestants, or declared to be believers that do not belong to a certain religion. 20 years after, the rates dramatically changed: the share of Atheists has greatly decreased $-23.8 \%$; there are much more Orthodox Christians - 23.4\%; but the greatest growth was noticed in the category considering themselves Orthodox Christian and Shamanist at the same time, there are $26.2 \%$ of them (other $-1.4 \%$ ). Therefore, there are four almost equal groups that were revealed: Atheist, Shamanist, Orthodox Christian and Orthodox Christian Shamanist.

Among men, the share of non-believers or adepts of the traditional cult relatively prevails; the majority of women identify themselves as Orthodox Christian or combine Orthodox Christianity with Shamanism (Table 15).

Between the generations, the difference in religious affiliation is not striking. Among the youth, the share of Atheists is slightly higher. But it does not mean that

Table 15. Religious affiliation of the Evenks (based on the surveys, in per cent)

\begin{tabular}{|l|c|c|c|c|c|}
\hline \multirow{2}{*}{} & \multicolumn{5}{|c|}{1997} \\
\cline { 2 - 6 } & Atheists & Shamanists & $\begin{array}{c}\text { Orthodox Christian } \\
\text { Shamanists }\end{array}$ & $\begin{array}{c}\text { Orthodox } \\
\text { Christians }\end{array}$ & Other \\
\hline Men & 47.9 & 32.0 & 5.7 & 12.9 & 1.5 \\
Women & 43.1 & 23.7 & 9.2 & 21.9 & 2.1 \\
\hline \multicolumn{7}{|c|}{2017} \\
\hline Men & 32.4 & 28.7 & 22.2 & 16.7 & - \\
Women & 20.8 & 20.8 & 28.7 & 27.5 & 2.2 \\
\hline
\end{tabular}


it will keep growing as the generations change. On the opposite, in the past 20 years this share has greatly decreased. Perhaps, many people turn to religion in their mature or senior age. However, at the present time even among young people aged under 30, Atheists are the minority: $28.9 \%$ (for middle adulthood, this share is $20.6 \%$ and $17.8 \%$ for the elderly age).

The tribal system has been gradually becoming a thing of the past (Vasilevich, 1972: 160-171); many respondents were confused with the question of their tribe, many of them mixed between the concepts of a tribe and a last name. Though very often last names were generated from the tribal names (Vasilevich, 1962: 99-100), they do not always coincide.

In the year 1997, 40.1\% of the respondents could name their tribe. However, in the past 20 years the process of "forgetting" has been sustained. The interest to history and the past raised the awareness of the tribal structure. In the year 2017, there were $47.0 \%$ of the respondents who could identify their tribe. Among the elderly people, the share was $70.4 \%$, for middle adults it was $62.9 \%$, and among the youth it constituted $34.4 \%$. But these figures do not mean that this rate will inevitably fall as the generations change. The same proportion was found in 1997, but within the past two decades the awareness has increased in all the age categories of the respondents.

In the past centuries, marriages between the Evenks and Russians were an occasional, not a massive phenomenon. Such marriages were common only for the groups of the Evenks who had abandoned their traditional lifestyle, given up reindeer breeding to choose sedentary lifestyle and peasant work. In the community of nomad reindeer breeders such marriages were unthinkable. Marriages with representatives of other Northern ethnicities living the same or similar lifestyle from the economic and household points of view were a different thing. For the vast territories of East Siberia and the Far East, mixed Yakut-Evenki groups were typical. In the territory of the Okrug, this process was and still is developing in the North-East territories, where the Evenks live side by side with a large Yakut community (Dolgikh, 1946: 483; Savoskul, 1970: 182).

A great number of mixed marriages with the migrant population was made in the post-war period or even later, starting from the 1960-s (Savoskul, 1970: 189-190), that was facilitated by the settlement of the Evenks in mixed villages, the change in their lifestyle assimilated to a European model. It was an effect of keeping children at hostel schools. By the end of the 1970-s, a third of the Evenks in the Okrug had got involved in mixed marriages and this share was continuously growing (Krivonogov, 1992: 4950). The number of mixed marriages is directly related to the ethnic composition of 
the settlements. In the monoethnic ones (Surinda, Uchami) the share of such marriages was relatively small, in the mixed ones (Tutonchany, Poligus) the rate was growing and in the predominantly Russian ones it reached its maximum.

In 1997, the rate of mixed families among the Evenks was 40.6\%, including 27.2\% with Russians, 7.7\% with people of other Siberian ethnicities (mostly, with the Yakuts), and $5.7 \%$ with other Caucasians (Ukrainians, Belarusians, Germans, etc.). 20 years after, the share of the mixed families has increased to $46.2 \%$. The growth is prominent, but it is relatively small. The families mixed with Russians constitute $32.9 \%$, with other Siberian ethnicities $-6.3 \%$, with other Caucasians $-7.0 \%$.

Depending on the ethnic composition of the settlement, the proportion of marriages significantly varies, but in the past 20 years there have been no significant changes (Table 16).

In the year 1997, 20\% of men were involved in mixed marriages (including to women of Mongoloid ethnicities - 9.5\%, to Russians and other Caucasians - 10.5\%). For women, the statistics are different. A half were involved in mixed marriages $50.0 \%$, including those married to Caucasians $-44.3 \%$. Now, 20 years have passed. The proportions have increased, but not that dramatically. 22\% of the Evenks are married to women of other ethnicities, including Caucasian $-15.2 \%$. For women, the total rate is $53.5 \%$, including those married to Caucasian men $-46.7 \%$.

The endogamy breakout caused the massive miscegenation of the Evenks. Among those interviewed in 1997, the Evenks of mixed descent constituted 50.2\% (Table 17). The Evenks of mixed descent are those who have representatives of other ethnicities in their genealogy. The ethnicity of the ancestors was found in the survey where the respondents were offered to name their closest ancestors to the second-third generation in the line of ascent. The share of the Evenks of mixed descent with this or that share of the Caucasian component (having Russians or other Caucasians in their genealogy) reached $40.5 \%$. 20 years after, miscegenation spread out dramatically; now, the share of the pure Evenks constitutes only $35.1 \%$, with the remaining $64.9 \%$ are of mixed descent. 50.9\% of them have a Caucasian component (the others come from the mixed families with other Siberian or Northern ethnicities, predominantly the Yakuts).

Naturally, in the mixed settlements the share of people of mixed descent is higher, while in the monoethnic ones it is lower (Table 18).

The distribution of the mixed generation by age groups proves that with the succession of generations, their share is growing, and among the children it has reached its maximum (Tables 19, 20). 
Table 16. Share of ethnically mixed families in the settlements of various ethnic compositions

\begin{tabular}{|l|c|c|c|}
\hline \multirow{2}{*}{} & \multicolumn{3}{|c|}{ Ethnic composition of the settlements } \\
\cline { 2 - 4 } & Evenki & Mixed & Russian \\
\hline 1997 & 12.6 & 44.6 & 59.8 \\
2017 & 15.6 & 42.4 & 58.1 \\
\hline
\end{tabular}

Table 17. Share of different types of the Evenks of mixed descent (based on the surveys, in per cent)

\begin{tabular}{|l|c|c|c|c|}
\hline & \multicolumn{4}{|c|}{ Ancestry } \\
\cline { 2 - 5 } & Evenks & $\begin{array}{c}\text { Evenks and other } \\
\text { Mongoloid ethnicities }\end{array}$ & $\begin{array}{c}\text { Evenks, Mongoloid and } \\
\text { Caucasoid ethnicities }\end{array}$ & $\begin{array}{c}\text { Evenks and Caucasoid } \\
\text { ethnicities }\end{array}$ \\
\hline 1997 & 49.8 & 9.7 & 7.3 & 33.2 \\
2017 & 35.1 & 14.0 & 11.6 & 39.3 \\
\hline
\end{tabular}

Table 18. Share of different types of the Evenks of mixed descent in the settlements of different ethnic composition (based on the surveys, in per cent)

\begin{tabular}{|l|c|c|c|c|}
\hline \multirow{2}{*}{$\begin{array}{c}\text { Ethnic } \\
\text { types of } \\
\text { settlements }\end{array}$} & \multicolumn{4}{|c|}{ Ancestry } \\
\cline { 3 - 5 } & Evenks & $\begin{array}{c}\text { Evenks and other } \\
\text { Mongoloid ethnicities }\end{array}$ & $\begin{array}{c}\text { Evenks, Mongoloid and } \\
\text { Caucasoid ethnicities }\end{array}$ & $\begin{array}{c}\text { Evenks and Caucasoid } \\
\text { ethnicities }\end{array}$ \\
\hline 1997 & & 11.1 & 4.1 & 20.3 \\
Evenki & 64.5 & 4.2 & 4.8 & 37.2 \\
Mixed & 53.8 & 14.1 & 13.2 & 41.2 \\
Russian & 31.5 & 8.6 & 6.5 & 26.9 \\
2017 & & 13.8 & 11.0 & 42.2 \\
Evenki & 58.0 & 16.1 & 13.7 & 42.8 \\
Mixed & 33.0 & & & \\
Russian & 27.4 & &
\end{tabular}

Table 19. Share of the Evenks of mixed descent in different age groups (based on the survey of the year 1997, in per cent)

\begin{tabular}{|l|c|c|c|c|}
\hline \multirow{2}{*}{ Age } & \multicolumn{4}{|c|}{ Ancestry } \\
\cline { 2 - 5 } & Evenks & $\begin{array}{c}\text { Evenks and other } \\
\text { Mongoloid ethnicities }\end{array}$ & $\begin{array}{c}\text { Evenks, Mongoloid and } \\
\text { Caucasoid ethnicities }\end{array}$ & $\begin{array}{c}\text { Evenks and } \\
\text { Caucasoid ethnicities }\end{array}$ \\
\hline 70 and older & 71.4 & 14.3 & 14.3 & - \\
$60-69$ & 69.4 & 13.9 & - & 16.7 \\
$50-59$ & 74.0 & 8.0 & 6.0 & 12.0 \\
$40-49$ & 74.5 & 11.8 & 1.0 & 12.7 \\
$30-39$ & 65.3 & 9.7 & 6.9 & 18.1 \\
$20-29$ & 43.6 & 9.8 & 8.3 & 38.3 \\
$10-19$ & 35.3 & 10.9 & 8.1 & 45.7 \\
Under 10 & 37.5 & 7.1 & 10.0 & 45.4 \\
\hline
\end{tabular}


Table 20. Share of the Evenks of mixed descent in different age groups (based on the survey of the year 2017, in per cent)

\begin{tabular}{|l|c|c|c|c|}
\hline \multirow{2}{*}{ Age } & \multicolumn{4}{|c|}{ Ancestry } \\
\cline { 2 - 5 } & Evenks & $\begin{array}{c}\text { Evenks and other } \\
\text { Mongoloid ethnicities }\end{array}$ & $\begin{array}{c}\text { Evenks, Mongoloid and } \\
\text { Caucasoid ethnicities }\end{array}$ & $\begin{array}{c}\text { Evenks and } \\
\text { Caucasoid ethnicities }\end{array}$ \\
\hline 70 and older & 81.8 & 18.2 & - & - \\
$60-69$ & 76.5 & 23.5 & - & - \\
$50-59$ & 57.4 & 21.3 & 8.5 & 12.8 \\
$40-49$ & 50.0 & 11.4 & - & 38.6 \\
$30-39$ & 32.8 & 17.9 & 7.5 & 41.8 \\
$20-29$ & 40.5 & 10.7 & 11.9 & 36.9 \\
$10-19$ & 25.0 & 9.7 & 12.5 & 52.8 \\
Under 10 & 10.2 & 14.8 & 22.2 & 52.8 \\
\hline
\end{tabular}

Previously, the share of children of mixed descent was 62.5\%, and now, 20 years after, it is $89.8 \%$, which means that 9 of 10 the Evenki children have parents of different ethnicities.

The share of the population mixed with the Yakuts is much less than that with Russians or other Caucasians, but it is also gradually growing. Previously, this or that share of the Yakut component in their genealogy was claimed by $15.4 \%$ of the Evenks; now this value has reached $19.3 \%$.

Mixing with the Yakuts is mostly happening in the Northern part of Evenkia (former Ilimpiysky District). Here, the share of the Evenks with a Yakut component in the genealogy constituted $23.4 \%$ in the past, while now it is $33.5 \%$. In the South (former Baykit District) it is much less: 5.7\% in 2017.

Into the "mixed Evenks" category we included only those children from mixed families, whose parents belong to the Evenki ethnicity. The opinion of the parents of their children's ethnicity was asked during the survey. To describe the nature and reveal the trends of the ethnic processes, to clarify the demographic situation it is important to know how many children of mixed descent identify themselves as Evenks later and how many of them prefer to choose other ethnicities.

If previously it was common to define the ethnicity by father (Savoskul, 1970: 190-191), now this order has been broken. It was found that in the year $199780 \%$ the Evenki children of mixed descent become Evenks regardless of their fathers' ethnicity. In 2017, the figure remained almost the same, 81.9\%. On one hand, it improves the demographic statistics and proves that being an Evenk is prestigious, that self-consciousness of the ethnos is stable. On the other hand, it brings some inevitable consequences, such as a massive inflow of half-bloods with weaker ethnic 
features (worse command of the ethnic language, less competence of the ethnic culture) "dilutes" and "diffuses" the ethnos, accelerating assimilation processes in culture and language. It is important that the subject matter is language and cultural assimilation, not the complete one associated with the replacement of ethnic selfconsciousness. Here, on the opposite, the Evenks happen to be assimilating Russians, as the children of mixed descent choose being Evenk quite frequently. Indeed, to a certain extent the situation is influenced by the allowances established for the smallnumbered indigenous peoples of the North by the government. However, in reality, the people of mixed descent, having no command of their ethnic language or culture, "in their heart" identify themselves with an indigenous ethnicity, which was proven by interviews with many of them.

Due to the mixed accommodation system, the majority of the Evenks work in mixed worker associations (61.2\% in $1997,64.4 \%$ in 2017). It does not evoke any negative reaction: in 1997, $73.3 \%$ of respondents were positive or neutral about working in a mixed group, and only $22.7 \%$ responded that they would prefer to work in their ethnic environment. The rates in 2017 were $74.8 \%$ and $16.9 \%$ correspondingly.

The attitude towards the ethnically mixed marriages proves the same mindset. Here the opinions are similar: in 1997, 71.6\% of men and 73\% of women would prefer a mixed marriage to a monoethnic or felt that the ethnicity made no difference in marriage; $23.7 \%$ of men and $21.7 \%$ of women responded that a monoethnic marriage would be preferable to them. In 2017, the rates for men were $72.1 \%$ and $76.8 \%$ (positive or neutral attitude); a monoethnic marriage would be preferable for $25.8 \%$ of men and $19 \%$ of women.

The intimate interethnic contacts of the Evenks are proven by the presence of friends belonging to other ethnicities. In 1997, 59\% of the respondents were involved in such friendly relationships, and now this value is $71.3 \%$.

The deployed process of language and cultural assimilation made a certain impact on the responses about the future of the ethnicity. In 1997, only $16 \%$ of the respondents believed that the Evenks would preserve themselves as an ethnos 2-3 generations after, $7.1 \%$ expressed less confidence in that and $12 \%$ were undecided, and the majority expressed a pessimistic point of view saying that the ethnos is threatened with extinction within several decades: 64.9\%. 20 years later, the statistics have not significantly changed: $17.2 \%$ are sure about the future of the ethnos and $57.1 \%$ are sure about the opposite. 


\section{Conclusion}

The decreasing significance of reindeer breeding observed in the 1990-s made a great impact on the ethnic processes of the Evenks in the view of enhancing the assimilation tendencies. The most optimistic forecasts concern the preservation of hunting and fishing as hobbies done in free time. Obviously, in the foreseeable future the Evenks are expected to remain faithful to these activities. However, this is only true for men: women tend to go to taiga less and less.

There is little hope for the preservation of Evenki language in everyday communication. In the generation of children, it has become a second language spoken only to the ethnic language teacher. Their true mother tongue is Russian. It is especially regrettable, since the Evenks are one of the ethnicities who, unlike many other smallnumbered indigenous peoples, have had an opportunity to study it at schools for a long time. However, it seems like the main mechanism of passing the language on to another generation lies in the family, not at school, and it is supposed to work from the moment the child is born, not from the age of seven. If this language succession mechanism in the family is broken, the school is unable to make any radical changes in that, and it is hard to blame the school. The dynamics of the contemporary language processes is unambiguous and easy to identify: the Evenks are rapidly transforming into a Russian-speaking ethnos. It is worthwhile noticing, however, that the efforts of the school are not fruitless: the decrease of language relevance is quite slow. It means that the school, introduction of writing and publications in the ethnic language are incapable of preventing the language assimilation, but they can make it slower to a certain extent.

Some kinds of spiritual culture turned out to be surprisingly steady, and the tribute should be obviously paid to schools and cultural institutions. Even though folklore is not addressed by the majority of the Evenks, such genres as songs and fairy tales still make a difference for some of them, maintaining the statistics at the same level. The memory of the basic rituals is also well preserved, though they are practiced less and less. In the past decades, the religious philosophy revival has been noticed; currently, the Evenks identify themselves as Atheists, Orthodox Christians or adepts of the traditional cult. However, in the essence this division is conventional, and the syncretism, where every Evenk bears a piece of each major ideological doctrine in his or her world outlook, is obvious.

In different areas of the material culture, the processes of break with the tradition are quite uneven. A traditional house can be hardly found, just like national clothes. 
But the ethnic cuisine is still there, even though it is not the same. First of all, only some of the dishes are remembered, and, secondly, in all cases traditional food is combined with Russian cuisine. Obviously, Evenki diet is expected to be like this for a long time; at least, no dramatic change is expected in the foreseeable future.

Rapid and irreversible changes in the Evenki gene pool are explained by the massive expansion of ethnically mixed marriages. Even though the share of the mixed marriages is growing slowly, it has reached the point where the Evenks begin to transform into "half-blooded population". With the natural succession of generations, all the Evenks will sooner or later have a mixed descent. At the same time, they keep a stable selfidentification, and there are no symptoms of any changes in this field. The majority of people born in mixed families identify themselves as an Evenk, improving the demographic statistics. Assimilation in culture and language does not cause a complete assimilation described as a change of ethnic self-consciousness or the dissolution of the Evenks in the surrounding Russian majority.

This way, it is possible to say that the Evenks remain a stable ethnic unit, preserving itself as an ethnos with the same ethnonym, but with a new language and a new anthropological appearance. In other words, the Evenks are becoming a group of mixed descent and speaking Russian language, preserving its initial ethnic selfconsciousness together with some elements of the material and spiritual culture.

\section{References}

Anderson, D.G. (1991). Turning hunters into herders: A critical examination of Soviet development policy among the Evenki of southeastern Siberia. In Arctic, 12-22.

Anderson, D.G. (1998). Property as a way of knowing on Evenki lands in Arctic Siberia. In Property relations: Renewing the anthropological tradition, 64-84.

Dolgikh, B.O., Chard, C.S. (1972). The formation of the modern peoples of the Soviet north. In Arctic Anthropology, 17-26.

Dolgikh, B.O. (1946). Rodovoy i plemennoy sostav narodnostey severa Sredney Sibiri [Generic and tribal composition of the North Siberian ethnicities]. Moscow.

Grenoble, L.A., Whaley, L.J. (1999). Language Policy and the Loss of Tungusic Languages. In Language \& Communication, 19(4), 373-386.

Koptseva, N.P., Kirko, V.I. (2014). Modern specificity of legal regulation of Cultural Development of the Indigenous Peoples of the Arctic Siberia (the Altay Region, the Zabaikailsky Region, Republic of Buryatia, Russia). In Life Science Journal, 11(9), 314-319. 
Koptseva, N.P., Kirko, V.I. (2014). The information basis for formation of positive ethnic identities in the process of acculturation of indigenous peoples of the Arctic Siberia (Krasnoyarsk, Russia). In Life Sci J, 11(8), 479-483.

Koptseva, N.P., Kirko, V.I. (2015). The impact of global transformations on the processes of regional and ethnic identity of indigenous peoples Siberian Arctic. In Mediterranean Journal of Social Sciences, 6(3 S5), 217-223.

Krivonogov, V.P. (2001). Zapadnye evenki na rubezhe tysyacheletiy [West Evenks at the turn of the millennia]. Krasnoyarsk.

Krivonogov, V.P. (2001). Izmeneniia v etnicheskikh protsessakh u zapadnykh evenkov $\mathrm{v}$ kontse XX veka [Changes in the ethnic processes of the West Evenks at the end of the $20^{\text {th }}$ century]. In Istoricheskiy ezhegodnik [History annals], special edition. Omsk.

Krivonogov, V.P. (2001). Transformatsiia kul'tury evenkov [Transformation of the Evenki culture]. In Geografiia na sluzhbe nauki, praktiki i obrazovaniia [Geography at the service of science, practice and education]. Krasnoyarsk.

Krivonogov, V.P. (1992). Evenki basseyna Eniseiia [The Evenks of the Yenisei basin] (co-authored). Novosibirsk.

Leonard, W.R., Katzmarzyk, P.T., Comuzzie, A.G., Crawford, M.H., Sukernik, R.I. (1994). Growth and nutritional status of the Evenki reindeer herders of Siberia. In American journal of human biology, 6(3), 339-350.

Libakova, N.M., Sitnikova, A.A., Sertakova, E.A., Kolesnik, M.A., Ilbeykina, M.I. (2014). Modern practices of regional and ethnic identity of the Yakuts (North Asia, Russia). In Life Sci J, 11(12), 133-140.

Mamontova, N.A. (2014). What Language Do Real Evenki Speak? Discussions Surrounding the Nomad Preschool. In Anthropology \& Archeology of Eurasia, 52(4), 37-75.

Reznikova, K.V., Zamaraeva, J.S., Kistova, A.V., Pimenova, N.N. (2014). The current state of traditional socio-cultural practices of indigenous peoples of the North (on the example of cultures of Selkups, Nenets and Essey Yakuts). In Life Sci J, 11(12): $126-132$.

Savoskul, S.S. (1970). Etnicheskie izmeneniia v Evenkiyskom natsional'nom okruge [Ethnic changes in the Evenki national district]. In Preobrazovaniia $v$ khoziaystve $i$ kul'ture $i$ etnicheskie protsessy u narodov Severa [Transformations in the household and culture, and ethnic processes of the Northern peoples]. Moscow.

Safonova, T., Sántha, I. (2011). Mapping Evenki land: The study of mobility patterns in Eastern Siberia. In Folklore, 49, 71-96. 
Simonova, V.V. (2012). The Evenki Memorial Tree and Trail: Negotiating with a Memorial Regime in the North Baikal, Siberia. In Journal of Ethnology and Folkloristics, 6 (1), 49-69.

Ssorin-Chaikov, N. (2001). Evenki shamanistic practices in Soviet present and ethnographic present perfect. In Anthropology of Consciousness, 12(1), 1-18.

Strakach, Iu.B. (1962). K voprosu o proizvodstvennykh tendentsiiakh evenkov [To the question of industrial tendencies of the Evenks]. In Kratkie soobshcheniia instituta etnografii AN SSSR (KSIE) [Short messages of the Ethnography Institute of the Academy of Sciences of the USSR (KSIE)], 37.

Tugolukov, V.A. (1965). Izmeneniia v khoziaystve i byte evenkov Irkutskoy oblasti za poltora veka [Changes in the household and economy of the Evenks of the Irkutsk Oblast for the past one hundred and fifty years]. In Sovetskaia etnografiia [Soviet ethnography], 3.

Tugolukov, V.A. (1963). U evenkov zapadnoy chasti Evenkiyskogo natsional'nogo okruga i Turukhanskogo rayona Krasnoiarskogo kraia [Visiting the Evenks of the Western part of the Evenki national district and the Turukhansk District of the Krasnoyarsk Territory (Krai). In Sovetskaia etnografiia [Soviet ethnography], 3.

Tugolukov, V.A. (1962). U evenkov reki Chuni i verkhov'ev Viliuia [Visiting the Evenks of the Chunya River and the Vilyuy headwaters], In Kratkie soobshcheniia instituta etnografii AN SSSR (KSIE) [Short messages of the Ethnography Institute of the Academy of Sciences of the USSR (KSIE)], 32.

Tugolukov, V.A. (1963). Khantayskie evenki (ocherk istorii, khoziaystva i kul'tury) [The Khantay Evenks (description of history, household and culture). In Trudy instituta etnografii AN SSSR (TIE) [Works of the Ethnography Institute of the Academy of Sciences of the USSR (TIE)], 84.

Tugolukov, V.A. (1974). Evenki basseyna reki Turukhan [The Evenks of the Turukhan River basin]. In Sotsial'naia organizatsiia i kul'tura narodov Severa [Social organization and culture of the Northern peoples], Moscow.

Tugolukov, V.A. (1980). Evenki i eveny [The Evenks and the Evens]. In Semeynaia obriadnost' narodov Sibiri: opyt sravnitel'nogo izucheniia [Family rituality of the Siberian peoples: comparative survey experience]. Moscow.

Tugolukov, V.A. (1960). Ekondskie evenki [The Ekonda Evenks]. In Trudy instituta etnografii AN SSSR (TIE) [Works of the Ethnography Institute of the Academy of Sciences of the USSR (TIE)], 56.

Turov, M.G. (1982). K probleme rekonstruktsii modeli khoziaystva grupp evenkov taiozhnoy zony Sredney Sibiri (XVII - nachalo XX vv.) [To the problem of 
reconstruction of the household model of the Evenks of the Middle Siberian taiga areas ( $17^{\text {th }}$ - early $20^{\text {th }}$ centuries). In Material'naia kul'tura drevnego naseleniia Vostochnoy Sibiri [Material culture of the ancient population of the Eastern Siberia]. Irkutsk.

Turov, M.G. (1990). Khoziaystvo evenkov taiozhnoy zony Sredney Sibiri v kontse $X I X$ - nachale XXvv. [Household of the Evenks of the Middle Siberian taiga areas of the late $19^{\text {th }}$ - early $20^{\text {th }}$ centuries)]. Irkutsk.

Vasilevich, G.M., Levin, M.G. (1951). Tipy olenevodstva i ikh proiskhozhdenie [Types of reindeer breeding and their origins]. In Sovetskaia etnografiia [Soviet ethnography], 1.

Vasilevich, G.M. (1972). Nekotorye voprosy plemeni i roda u evenkov [Some tribal and generic issues of the Evenks]. In Okhotniki, sobirateli, rybolovy [Hunters, foragers, fishermen]. Leningrad.

Vasilevich, G.M. (1962). Evenki Katangskogo rayona [The Evenks of Katanga District]. In Sibirskiy etnograficheskiy sbornik [Siberian ethnographic digest], 78, 98-121.

Vasilevich, G.M. (1956). Evenki [The Evenki]. In Narody Sibiri [Peoples of Siberia]. Moscow, Leningrad.

Whaley, L.J. (2011). Some ways to endanger an endangered language project. In Language and Education, 25(4), 339-348.

\section{Социокультурная динамика этнических процессов эвенков}

В.П. Кривоногов, Е.С. Ермилова Сибирский федеральный университет Россия, 660041, Красноярск, пр. Свободный, 79

В 1997 и в 2017 годах в Эвенкии были проведены комплексные исследования по современным этническим процессам с использованием метода массового опроса. Выявлень существенные изменения в хозяйстве, в разных областях материальной и духовной культуры. Резко снизилось значение оленеводства, в настоящее время в нем занять около 1/10 части эвенкийских семей. Лучше сохранились охота и рыболовство, в них занята почти треть мужчин. На любительском уровне охотой и рыболовством занимается подавляющее большинство мужчин, а значительная часть женщин не утеряли навыков шитья и вышивки бисером. Активно идет процесс языковой ассимиляции, дети практически не говорят на языке эвенков и не понимают его, хотя большинство эвенков изучает родной язык в школе. Количество национально-смешанных семей, в 
основном с русскими, приблизилось к половине всех семей, большинство детей вливаются в эвенкийский этнос. В результате этих браков доля метисов среди эвенков приближается к 2/3, а среди детей их доля достигла 9/10. Эвенки преврашаются в группу русскоязычных метисов, но с устойчивым этническим самосознанием и с сохранением элементов традиционной культуры в некоторых областях материальной и духовной культуры.

Ключевые слова: этнические процессы, языковая ассимиляџия, национально-смешанные браки, метисачия, этническое самосознание.

Исследование выполнено при поддержке $А O$ «Востсибнефтегаз» в рамках реализации проекта по выполнению научно-исследовательских работ «Возрождение эвенкийского языка».

Научная специильность: 22.00.00 - социология. 